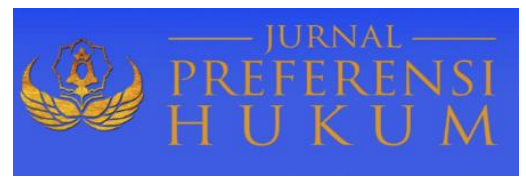

Jurnal Preferensi Hukum | ISSN: XXXX | E-ISSN: XXXX

Vol. 1 No. 1 - Juli 2020 hal. 234-238| Available online at https://www.ejournal.warmadewa.ac.id/index.php/juprehum

\title{
PERLINDUNGAN HUKUM TERHADAP PENGUSAHA SEWA MENYEWA KENDARAAN BERMOTOR YANG DIRUGIKAN OLEH KONSUMEN PADA PERUSAHAAN PAULUS RENTAL BIKE KABUPATEN BADUNG
}

\author{
Philipus Dian Anjaraka, I Nyoman Putu Budiartha, Luh Putu Suryani \\ Fakultas Hukum Universitas Warmadewa, Depnasar - Bali, Indonesia
}

\begin{abstract}
Abstrak
Perkembangan sektor industri kendaraan bermotor pada saat ini sangat berkembang pesat baik yang diproduksi di dalam negeri maupun yang import dari luar negeri sehingga di dalam bisnis ini seperti produsen, dealer dan pedagang kendaraan saling berlomba-lomba untuk memberikan kemudahan-kemudahan kepadan para konsumen guna meningkatkan omset perdagangan. Dalam penelitian ini membahasas tentangupaya penyelesaian sengketaantara pemilik usaha yang dirugikan oleh konsumen dalam proses non-litigasi, serta menganalis is hambatan apa yang terjadi dalam penyelesaian sengketa ters ebut. Metode yang digunakan dalam penelitian ini adalah metode penelitian empiris . Data yang digunakan adalah data primer dan sekunder. Hasil penelitian menunjukan bahwa upaya penyelesaian sengketa antara pemilik usaha khususnya penyewaan kendaraan bermotor saat dirugikan oleh konsumen dilakukan dengan cara non litigasi yaitu dengan menggunakan salah satu alternatif penyelesaian sengketa di luar pengadilan dengan mekanisme mediasi dan negosiasi kepada pihak penyewa yan g telah meminta maaf dengan mengemballikan uang yang disepakati kedua belah pihak. Selain itu, faktor penghambat dalam upaya penyelesaian sengketa antara pemilik usaha yang dirugikan konsumen dalam proses penyelesaian sengketa yaitufaktoraturan hukum. Dalam hal ini dikarenakan kerugian tersebut tergolong dalam ranah perdata, maka memerlukan waktu untukmembuktikan kerugian yang harus mendapat legalitas dari pengadilan. Tidak hanya aturan hukum, tetapi juga factor penegak hukum yang memproses perkara kerugian begitu lamadan lambat.
\end{abstract}

Kata Kunci: Perlindungan hukum; Penyewaan Kendaraan; Konsumen

\begin{abstract}
The development of the motor vehicle industry sector is currently growing rapidly both domestically and imported from abroad so that in this business such as manufacturers, dealers and traders of vehicles competing with each other to provide facilities to consumers in order to increase turnover trading. In this research, it discusses efforts to resolve disputes between business owners who are harmed by consumers in the non-litigation process, and analyses the obstacles that occur in the resolution of such disputes. The method used in this study is the empirical research method. The data used are primary and secondary data. The results showed that efforts to resolve disputes between business owners, especially motor vehicle leasing when harmed by consumers, were carried out by non-litigation, namely by using an alternatifdispute resolution outside the court with mediation and negotiation mechanisms to the tenan ts who had apologized by returning the money agreed by both parties. In addition, the inhibiting factor in efforts to resolve disputes between business owners who are disadvantaged by consumers in the dispute resolution process is the rule of law factor. In this case because the loss is classified in the civil realm, it requires time to prove the loss that must get legality from the court. Not only the rule of law, but also law enforcement factors that process cases for so long and slow respond.
\end{abstract}

Keywords: Legal protection; Vehicle Rental; Consumer

\section{PENDAhUluan}

Kata perlindungan sangat pasih disampaikan untuk membuat orang merasa aman, nyaman dan berkeadilan. Namun perlindungan juga bisa diartikan hak hakiki setiap warga negara untuk mendapat keamanan, kenyamanan yang berkeadilan dalam kehidupan. Sedangakan kata hukum itu berarti peraturan- peraturan yang berisikan perintah, larangan, yang berlandaskan norma, agama, yang berisikan sanksi-sanksi yang 
wajib di patuhi. Pada zaman sekarang ini kebanyakan orang sering membicarakan tentang hukum yang banyak diwarnai dan dibahas dengan berbagai topik tak terkecuali pembahasan mengenai perlindungan hukum(Sadar, 2015). Dalam hal ini pembahasan tersebut secara tidak langsung berkaitan erat dengan implementasi hukum di suatu daerah dan pembuat hukum itu sendiri. Berbicara mengenai perlindungan hukum, sangatlah penting untuk diketahui unsur-unsur dari perlindungan hukum itu sendiri karena hal tersebut merupakan salah satu hal terpenting dari penegakan keadilan di suatu negara hukum. Dianggap penting karena dalam pembentukan suatu negara akan dibentuk pula hukum yang mengatur tiap-tiap warga negaranya.

Sudah sangat lazim untuk diketahui bahwa kehidupan di masyarakat suatu negara akan terjadi suatu hubungan timbal balik antara warga negaranya yang berpedoman pada suaru aturan yang ada di suatu negara tersebut sebagai batasan norma yang dijalankan. Dalam hal tersebut akan melahirkan suatu hak dan kewajiban satu sama lain yaitu antara warga negara itu sendiri dengan cerminan kepantasan dari aturan perundang-undangan yang berlaku di Negara tersebut, oleh karena itu perlindungan hukum akan menjadi hak tiap warga negaranya.

Terkait dengan hubungan timbal balik, dalam penelitian iniakan membahas tentang sewa menyewa yang saling terikat oleh sebuah kesepakatan. Akan tetapi, pembahas dalam penelitian lebih terarah pada perlindungan hukum secara khusus pihak yang memberi sewa. perlu diketahui, kata 'sewa' dalam Bahasa Inggris dikenal denga istilah 'leasing'. Menurut (Fletcher, Freeman, Sultanov, \& Umarov, 2005) leasing adalah kemungkinan bagi UKM untuk memperluas akses mereka ke pembiayaan jangka pendek dan menengah. Dari perspektif ekonomi, leasing dapat didefinisikan sebagai "kontrak antara dua pihak di mana satu pihak (lessor) memberikan aset untuk digunakan ke pihak lain (lessee) untuk periode waktu tertentu, sebagai imbalan untuk pembayaran yang ditentukan". Penyewaan adalah instrumen alternatif untuk memfasilitasi akses ke keuangan; ini memungkinkan perusahaan baru/muda tertentu (termasuk yang disebut "gazelles") tanpa catatan kredit dan kemungkinan terbatas untuk memberikan jaminan penggunaan peralatan modal (Kraemer-Eis \& Lang, 2012).

Penelitian terkait permasalahan sewa-menyewa telah dilakukan oleh beberapa peneliti sebelumnhya, seperti yang dilakukan oleh (Badriyah, Mahmudah, Soemarmi, \& Kamello, 2019) menyatakan bahwa leasing dapat digunakan sebagai alternatif pembiayaan untuk usaha mikro, kecil dan menengah dalam pengembangan industri perikanan. Mengenai penyimpangan hukum yang tidak seimbang dan hubungan mengakibatkan kurangnya perlindungan hukum untuk usaha mikro, kecil dan menengah di industri perikanan. Oleh karena itu, di masa depan diperlukan peraturan khusus mengenai perjanjian sewa guna usaha, pengawasan pemerintah yang lebih optimal, jaminan pemerintah, pemuliaan prinsip-prinsip tersebut. Kdua, (Utami, Barowib, \& Ghofur, 2020) dalam temuan penelitianya mengungkapkan bahwa penerapan efisiensi, inovasi dan upaya syariah fintech diperlukan untuk meningkatkan minat konsumen dalam pengambilan keputusan pembelian kendaraan melalui leasing syariah di Indonesia.

Dari uraian penelitian di atas, maka penelitian baru ini bertujuan untuk menganalisis upaya penyelesaian sengketa antara pemilik usaha yang dirugikan oleh konsumen dalam proses non litigasi, serta menganalisis hambatan apa yang terjadi dalam penyelesaian sengketa tersebut.

\section{METODE PENELITIAN}

Penelitian ini menggunakan metode empiris dan kualitatis dimana dalam pengerjaannya peneliti menlaah isu hukum dengan didasari peraturan - peraturan hukum serta informasi narasumber (Ahmad, 2008).Pendekatan perundang-undangan dilakukan guna melihat, mencatat dan memahami permasalahan yang dikaji dalam penelitian ini dengan menetap pada zona hukum positif. Jenis data utama yaitu kepustakaan yang mengacu pada norma hukum yang terdapat dalam peraturan perundang-undangan dengan informasi dari narasumber (Waluyo, 2002). Dengan kata lain, teknik pengumpulan data tidak hanya dilakukan secara pustaka, tetapi melalui waawancara juga. Kemudian data yang terkumpul, dianalisis dan diinterpretasikan secara deskripsi sesuai patokan dasar-dasar hukum yang berlaku di Indonesia. 


\section{HASIL DAN PEMBAHASAN}

\section{Upaya Penyelesaian Sengketa antara Pemilik Usaha yang Dirugikan oleh Konsumen dalam Proses Non-litigasi}

Perlindungan hukum terhadap pelaku usahan penyewaan kendaraan bermotor pada dasarnya tergantung pada perjanjian awal dari sebuah perikatan sewa menyewa. Substansi atau point-point penting yang di dalam perjanjian haruslah sesuai dengan kesepakatan bersama tetapi sesuai dengan norma hukum yang berlaku tanpa adanya penyimpangan norma. Setiap pihak yang melakukan kerjasama mendiskusikan isi dari kerjasamayang nanti ditandatangani mulai dari sistem pembayaran, etikad para pihak yang bersangkutan sampai sanksi yang diterima jika salah satu pihak melakukan pelanggaran atau tidak mengikuti ketentuan suatu perjanjian yang telah disepakati bersama. Maksud dan tujuan dibuatnya perjanjian sebagai pengikat kedua belah pihak saling memikul tanggung jawab serta hak yang diperoleh masing-masing dan objek yang ada di perjanjian dapat aman tanpa harus memikirkan baranga yang disewakan akan hilang atau kondisi tidak seperti saat disewakan, apabila terjadi hal yang tidak diinginkan seperti kehilangan objek karena kesalahan penyewa maka pemilik dapat menuntut ganti rugi jika tidak menemui titik tengah akan diselesaikan melalui jalur pengadilan.

Berkaitan dengan biaya yang harus dipergunakan harus jelas agar saat penandatanganan perjanjian sudah sesuai keinginan kedua belah pihak, disamping itu pertukaran hak dan kewajiban masing-masing pihak menjadi faktor penting keberhasilan berkontrak guna mengantisipasi kecurigaan pihak yang merasa dirugikan, keaslian berkas atau surat baik itu dari penyewa maupun surat-surat objek yang ada dalam perjanjian harus sesuai. Antara pihak satu dan pihak dua jangan sampai terjadi salah komunikasi supaya kedepan tidak terjadi ingkar janji hanya karena setelah ditandatanganinya perjanjian kedua belah pihak tidak ada memberi kabar. Menurut (Anasjid, 2007) ada beberapa contoh klausa yang biasa tertera dalam sebuah perjanjian sesuai etikad baik para pihak serta norma yang berlaku saat ini sebagai berikut:

a. Kesepakatanterkait pembayaran objek yang disewakan. Para pihak yang melakukan suatu perjanjian secara sepakat menetapkan jumlah yang dibayarkan, bisa dibayar setengah di awal perjanjian dan sisanya di akhir perjanjian atau pembayaran dilakukan setelah selesai menandatangai kontrak yang di buat oleh kedua belah pihak.

b. Larangan memindahtangankan objek perjanjian, sebagai pihak yang menyewakan melarang keras pihak penyewa untuk meminjamkan orang lain bahkan sampai dipergunakan untuk hal-hal yang tidak benar dan sebagai pihak yang menyewa agar mentaati kesepakatan dari pihak penyewa agar kedepan dapat dengan mudah melakukan perjanjian dengan pihak yang sama. Kondisi objek saat awal perjanjian dan selesai kontrak harus sama dan kesepakatan para pihak kemungkinan kondisi objek tidak kembali seperti semula pihak penyewa menanggung biaya perawatan objek.

c. Pemberlakuan denda bagi pihak yang menyewa apabila terlambat membayar biaya yang telah disepakati kedua belah pihak harus di muat dalam perjanjian.

d. Disamping kesepakatan yang memberikan tanggung jawab sepenuhnya kepada pihak penyewa bila terjadi kerusakan harus dibuatkan asuransi oleh pihak yang menyewakan guna mengamankan kendaraan dari kelalaian pihak penyewa.

e. Antisipasi terjadinya wanprestasi yang banyak terjadi pada perjanjian - perjanjian sewa pakai mengharuskan kedua belah pihak mencantumkan seorang kuasa hukum. Fungsi kuasa hukum dalam perjanjian sebagai penjamin objek yang disewakan tidak dipergunakan untuk hal - hak yang tidak sesuai dengan isi perjanjian.

Alasan banyak terjadi wanprestasi karena salah satu pihak ada yang tidak setuju dengan isi perjanjian yang dibuat serta tidak ingin ambil pusing dan menginginkan hasil instan, akibatnya banyak diantara para pihak yang membuat perjanjian tidak dengan serius mengikuti isi kontrak mengakibatkan keuntunganhanya ada pada satu pihak. Ada beberapa cara yang dapat ditempuh saat terjadi wanprestasi yaitu melakukan penuntutan di pengadilan umum dan melalui penyelesaian tidak melalui pengadilan atau biasa disebut dengan ADR. Dewasa ini para pihak jarang melakukan penuntutan melalui pengadilan karena waktu yang dipergunakan begitu lama serta dana yang digunakan tidak sedikit, kebanyakan lebih menggunakan ADR dalam permasalahan wanprestasi. Sebagian permasalahan yang menggunakan jalur ADR dapat terselesaikan dengan waktu yang singkat tanpa mengeluarkan biaya yang banyak membuat para pihak tidak 
hanya menghabiskan waktu bolak balik pengadilan. Apabila jalur ADR tidak menjadikan titik tengah permasalahan barulah para pihak yang bersangkutan menggunakan alternatif tuntutan melalui pengadilan(Kristiyanti, 2014).

Wanprestasi (kelalaian) mempunyai akibat-akibat yang begitu penting, maka harus ditetapkan lebih dahulu apakah si konsumen melakukan wanprestasiatau lalai, dan kalau hal itu disangkal olehnya, harus dibuktikan di muka hakim. Kadang-kadang juga tidak mudah untuk mengatakan bahwa seseorang lalai atau alpa, karena seringkali juga tidak dijanjikan dengan tepat kapan sesuatu pihak diwajibkan melakukan prestasi yang dijanjikan. Dalam jual beli barang misalnya tidak ditetapkan kapan barangnya harus diantar ke rumah si pembeli, atau kapan si pembeli ini harus membayar uang harga barang tadi. Dalam hal seorang meminjam uang, sering juga tidak ditentukan kapan uang itu harus dikembalikan. Paling mudah untuk menetapkan seorang melakukan wanprestasi ialah dalam perjanjian yang bertujuan untuk tidak melakukan suatu perbuatan. Apabila orang itu melakukannya berarti ia melanggar perjanjian. Ia melakukan wanprestasi. Begitu pula, kalau saya memesan pakaian untuk saya pakai pada perayaan Hari Kemerdekaan, maka teranglah penjahit pakaian itu lalai, bila pada tanggal 17 Agustus pakaian tersebut belum selesai. Mengenai perjanjian untuk menyerahkan suatu barang atau untuk melakukan suatu perbuatan, jika dalam perjanjian tidak ditetapkan batas waktunya tetapi si berutang akan dianggap lalai dengan lewatnya waktu yang ditentukan, pelaksanaan prestasiitu harus lebih dahulu ditagih. Kepada debitur itu harus diperingatkan bahwa kreditur menghendaki pelaksanaan perjanjian.Kalau prestasi dapat seketika dilakukan, misalnya dalam jual beli suatu barang tertentu yang sudah di tangan si penjual, maka prestasi tadi (dalam hal ini menyerahkan barang tersebut) tentunya juga dapat dituntut seketika.Apabila prestasi tidak seketika dapat dilakukan, maka si berutang perlu diberikan waktu yang pantas.Misalnya dalam jual beli barang yang belum berada di tangan si penjual, pembayaran kembali uang pinjaman, dan lain sebagainya.

Seseorang dikatakan tidak memenuhi prestasinya jika dia tidak membayarkan biaya yang telah disepakati bersama, dimintakan oleh penyewa uang sewa serta tidak mengembalikan kendaraan yang menjadi objek sewa pakai bahkan kata lupa pun bisa menjadikan seseorang wanprestasi dan dapat dituntut dipengadilan. Siapa pun yang berani membuat perjanjian harus dapat bertanggung jawab, karena setiap perbuatan memiliki resiko masing - masing. Rugi atau kerugian merupakan suatu hal fatal dalam sebuah kontrak dapat dicontohkan pihak penyewa menggunakan kendaraan yang disewa namun terjadi suatu hal yang tidak diinginkan semisal kecelakaan atau tabrakan yang mengakibatkan kerusakan objek kontrak menjadi tanggung jawab pihak penyewa memberbaiki kendaraan serta mengganti kerugian yang diakibatkan kesalahannya. Sudah menjadi tanggung jawab pihak penyewa mengganti rugi kendaraan yang menjadi objek perjanjian dan sudah tertera dalam peraturan yang dibuat pemerintah serta memiliki sanksi bagi seseorang yang tidak mengganti rugi atau alpa namun sebagai pihak yang telah berkontrak tetap dapat perlindungan oleh peraturan pemerintah yang sesuai norma dan etikad baik perjanjian jika pihak penyewa sudah mengganti rugi atas perbuatannya.

Perlindungan hukum pemilik penyewaan kendaraan bermotor sebagai warga negara telah diberikan oleh aparat penegak hukum seperti kepolisian, akan tetapi kerugian bagi pengusaha pemilik motor tersebut menjadi lebih banyak, hal ini dikarenakan setelah kerugian akibat beberapa bulan motor tersebut digadaikan oleh pelaku, dan setelah motor tersebut diketahui fisiknya maka pengusaha penyewaan kendaraan berupa motor tersebut akan mengalamikerugian tambahan dikarenakan pengembalian motor kepada pengusaha tersebut menjadi lebih lama karena menunggu penyelesaian kasus hukum pelaku sampai dengan adanya keputusan pengadilan. Walaupun dana kerugian telah dikembalikan oleh si pelaku dan pengusaha penyewaan kendaraan bermotor telah memaafkan pelaku dengan metode penyelesaian sengketa di luar pengadilan, akan tetapi proses pidana tetap dilakukan. Hal ini dikarenakan motor NMax tersebut dijadikan barang bukti oleh aparat peneak hukum. Berkaitan dengan hal ini bahwa perlindungan hukum bagi pemilik kendaraan bermotor yang ditipu oleh konsumen tidak berjalan dengan baik, dikarenakan motor yang telah ditemukan tidak dapat dikembalikan secara langsung kepada pemilik usaha penyewaan kendaraan tersebut, Karena digunakan sebagai alat bukti. Dengan demikian kerugian pemilik usaha penyewaan kendaraan bermotor berupa motor NMax tersebut menjadi bertambah, karena dengan lamanya waktu selama berbulanbulan motor tersebut tidak dapat digunakan atau disewakan.Dalam hal ini dapat dikatakan bahwa perlindungan hukum perusahaan penyewaan kendaraan bermotor dengan motor NMax tersebut hanya 
sebatas untuk mendapatkan motor type NMax itu kembali tanpa menghitung ada perlindungan hukum tentang kerugian yang menimpa perusahaan penyewaan kendaraan bermotor tersebut.

\section{SIMPULAN DAN SARAN}

\section{Simpulan}

Upaya penyelesaian sengketa yang dapat dilakukan antara pemilik usaha khususnya penyewaan kendaraan bermotor saat dirugikan oleh konsumen dapat dilakukan dengan cara non litigasi seperti arbritase, negoisasi, mediasi, konsiliasi atau penilaian para ahli. Upaya penyelesaian sengketa yang digunakan adalah dengan mekanisme mediasi dan negosiasi denganpihak penyewa yang telah meminta maaf dengan mengembalikan uang yang disepakati kedua belah pihak.Faktor penghambat upaya penyelesaian sengketa antara pemilik usaha yang dirugikan konsumen dalam proses penyelesaian sengketa dengan metode non litigasi adalah faktor aturan hukum. Hal ini dikarenakan kerugian tersebut tergolong dalam ranah perdata, maka akan memerlukan waktu untuk membuktikan kerugian yang harus mendapat legalitas dari pengadilan. Sertafaktor penegak hukum kinerja penegak hukum yang cenderung berhati-hati dalam memproses perkara kerugian akan menjadikan proses berjalan lambat. Peranan penegak hukum yang dimaksud dalam hal ini adalah advokat yang dibutuhkan dalam penyelesaian sengketa tersebut maka factor penghambat selain faktor aturan hukum tersebut ialah faktor biaya untuk penyelesaian sengketa tersebut.

\section{Saran}

Melalui penelitian ini, peneliti menyarankan kepadapemerintah atau penegak hukum untuk ikut menjembatani setiap proses non litigasi baik dalam tahap mediasi ataupun negosiasi. Hal ini di maksudkan untuk mendapatkan hasil perdamaian yang maksimal dan para pihak tidak ada yang merasa dirugikan. Bagi masyarakat agar dapat memilih penyelesaian sengketa yang terbaik untuk menyelesaikan permasalahan sengketanya yang dapat di pilih antara penyelesaian sengketa secara litigasi maupun non litigasi. Kemudian, pemerintah diharapakan dapat menyediakan layanan untuk penyelesaian sengketa yang diajukan oleh para pihak terlibat mendapatkan fasilitas yang tepat dan waktu penyelesaian sengketa berlangsung singkat. Selanjutnya, masyarakat, yang memiliki kasus yang sama seperti yang dibahas agar lebih bijak dalam pengambilan keputusan dalam menyelesaikan sengketa, dan agar lebih baik untuk mengambil upaya penyelesaian sengketa dengan cara diluar pengadilan atau non-litigasi.

\section{DAFTAR PUSTAKA}

Ahmad, B. (2008). Metode Penelitian Hukum. Bandung: Pustakasetia.

Anasjid, C. (2007). Dasar-Dasar Ilmu Hukum. Jakarta: Sinar Grafika.

Badriyah, S. M., Mahmudah, S., Soemarmi, A., \& Kamello, T. (2019). Leasing agreement on financing SMEs in fisheries industry. Journal of Legal, Ethical and Regulatory Issues, 22(3).

Fletcher, M., Freeman, R., Sultanov, M., \& Umarov, U. (2005). Leasing in development: Guidelinesfor emerging economies. IFC.

Kraemer-Eis, H., \& Lang, F. (2012). The importance of leasing for SME finance. European Investment Fund. Luxembourg,.

Kristiyanti, C. T. S. (2014). Hukum Perlindungan Konsumen. Jakarta: Sinar Grafika.

Sadar, M. (2015). Hukum Perlindungan Konsumen. Bandung: Gramedia.

Utami, P., Barowib, \& Ghofur, R. A. (2020). Sustanaibility Strategy Management in Affecting Decisions for Purchase of Vehicles Through Leasing Shariah in Indonesia. AL-FALAH: Journal of Islamic Economics, 5(1), 22. https $/ /$ doi.org/10.29240/alfalah.v5i1.1342

Waluyo, B. (2002). Penelitian Hukum Praktek. Jakarta: Sinar Grafika. 